\title{
Holofraser og sondringen mellem leksikalske og grammatiske tegn: En tegntypologi og en fylogenetisk hypotese
}

\section{Kasper Boye \& Peter Harder}

\begin{abstract}
In this paper we place holophrases in relation to the contrast between lexical and grammatical signs. Based on Boye \& Harder (2012), we first argue that holophrases are neither lexical nor grammatical, but constitute a distinct third type of linguistic signs which is fundamentally different. Subsequently, we address the complication constituted by so-called formulaic expressions, and argue that these are not always holophrastic, but may be lexical and perhaps even grammatical. Finally, based on the proposed sign typology - and on the idea that complexity calls for a functionally motivated, structured division of labour - we present a hypothetical scenario for the phylogenesis of linguistic signs.
\end{abstract}

\section{Nøgleord}

holofrase, leksikalsk, grammatisk, formular, fylogenese

\section{Indledning}

Der er en lang sprogvidenskabelig tradition for at skelne mellem leksikalske og grammatiske tegn. I kinesisk sprogvidenskab kan en tilsvarende sondring mellem shici og xuci føres tilbage til en mere vag skelnen mellem shi og xu, der stammer fra Songdynastiet (960-1279 e.Kr.) (Harbsmeier 1979: 159-162; He 1998). I europæisk sammenhæng kan sondringen spores helt tilbage til i hvert fald Aristoteles og hans oversætter Boethius, der skelnede mellem significativa og consignificativa, og til Priscians sondring mellem categoremata og syncategoremata, der spillede en betydelig 
rolle i middelalderens logik og sprogfilosofi (Lyons 1968: 273; Klima 2005; Kirchhoff 2008: Ch. 2; Spruyt 2011). Inden for denne tradition er der bred enighed om, at $\mathrm{fx}$ verber og substantiver tilhører den første gruppe tegn, mens artikler, hjælpeverber og bøjningsaffikser tilhører den anden. Andre tegnklasser er sværere at placere, fx adpositioner og pronomener. ${ }^{1}$

Såkaldte holofraser udgør en særlig udfordring for sondringen. De voksensprogsholofraser, der kendes under navnet interjektioner, antages som oftest at være grammatiske (fx Gkalitsiou et al. 2017: 792). Men når det gælder børnesprogsholofraser, harmonerer denne antagelse dårligt med det forhold, at det såkaldt holofrastiske stadie i sprogtilegnelsen ligger forud for det telegrafiske stadie, der er kendetegnet ved, at grammatiske ord endnu er få eller fraværende. Så hvad er holofraser? Er de grammatiske tegn, leksikalske tegn eller en helt tredje type tegn?

I denne artikel vil vi placere holofraser i forhold til den funktionelle sondring mellem grammatiske og leksikalske tegn, vi har udarbejdet i bl.a. Boye \& Harder (2012). På baggrund af en kort præsentation af den funktionelle sondring (afsnit 2) vil vi argumentere for, at holofraser hverken er leksikalske eller grammatiske (afsnit 3), men udgør en selvstændig tegntype, der er væsensforskellig fra begge (afsnit 4). Efterfølgende udvider vi perspektivet til at omfatte såkaldte formularer, dvs. komplekse tegn, der kognitivt antages at være lagret som helheder, og vi argumenterer med skelen til afasiforskningen for, at sådanne formularer kan være enten holofraser, leksikalske tegn eller måske endda grammatiske (afsnit 5). Med afsæt i sondringen mellem tre slags tegn opstiller vi derpå en hypotese om de sproglige tegns fylogenese (afsnit 6), hvorefter vi kort opsummerer (afsnit 7).

\section{En funktionel teori om forskellen på leksikalske og grammatiske tegn: Grammatiske størrelser som resultat af prioritering}

Processering af kompleks information kræver prioritering. Det gælder ikkesproglig information, fx i forbindelse med billeder, men også sproglig information. Efter vores mening (fx Boye \& Harder 2012) er kontrasten mellem grammatiske og leksikalske tegn et led i de mekanismer, der be-

1 Mht. argumenter for, at sådanne tegnklasser kan være heterogene og omfatte både leksikalske og grammatiske medlemmer, se fx Ishkhanyan et al. (2017) om franske pronomener og Messerschmidt et al. (2018) og Boye et al. (2019) om danske præpositioner. 
stemmer prioriteringen af information i en kompleks ytring. Den repræsenterer en konventionalisering af en kontrast, der har at gøre med informationsprioritering. (For en nærmere redegørelse for, hvordan vi opfatter konventionalisering, se Boye \& Harder 2012). Leksikalske tegn (morfemer, ord, konstruktioner) er tegn, der pr. konvention er potentielt diskursivt primare (forgrund). De kan, men behøver ikke, udtrykke hovedsagen i en ytring. Om de gør det, afhænger af konteksten. Betragt fx en ytring som (1), der består af to leksikalske elementer (verbet undgå og substantivet $k a ̊ l)$.

\section{Undgå kål!}

I nogle kontekster vil undgå udtrykke det vigtigste indhold og altså være diskursivt primært, fx i en samtale om, hvordan man skal forholde sig til kål. I andre kontekster vil kål være primært, fx i en samtale om, hvad man bør undgå.

Grammatiske tegn (morfemer, ord, konstruktioner) adskiller sig fra leksikalske derved, at de ikke har potentialet til at udtrykke hovedsagen i en ytring. De er pr. konvention diskursivt sekundare (baggrund). Dvs. de er diskursivt sekundære uden for metasproglige (herunder korrigerende) kontekster, hvor de sproglige konventioner brydes. Det gælder således, at grammatiske tegn er konventionaliseret med en af de to mulige diskursprominensværdier for leksikalske tegn, nemlig at være 'diskursivt sekundær'. Leksikalske tegn kan derimod både optræde som diskursivt primære og diskursivt sekundære.

Kontrasten mellem leksikalske og grammatiske tegn hjælper os med at afgøre, hvilken del af en kompleks ytring vi skal rette vores opmærksomhed imod. I eksemplet nedenfor er de ord, der er markeret med fed, leksikalske, dvs. de kan læses som det primære indhold, hvilket kan konstateres ved at læse eksemplet op med fokus-intonation efter tur på hvert af de leksikalske ord.

\section{Den gamle dekan har altid ønsket at købe en Rafael.}

Derimod kunne man fx ikke gøre at til bærer af det primære indhold. Dette ord er konventionelt indrettet til at træde i baggrunden.

Det at være konventionelt designet til at udtrykke diskursivt sekundært indhold er den ene af de to egenskaber, der kendetegner grammatiske tegn. Den anden egenskab er en konsekvens af den forste: Fordi grammatiske 
størrelser ikke kan være diskursivt primære i sig selv, er de afhængige ('dependente') i forhold til et andet tegn, deres 'vært'?

\section{Holofraser}

Vi vil nu diskutere spørgsmålet, om holofraser er leksikalske, grammatiske eller en helt tredje type tegn. Ved holofraser forstår vi tegn, der kan danne en ytring alene, som ikke kan indgå i forbindelse med andre tegn, og som er simple i den forstand, at de ikke kan segmenteres i mindre tegnbestanddele. Holofraser omfatter således interjektioner som i (3) og (4), børnesprogstegn, der nok kan segmenteres af den voksne, men som for barnet er usegmenterbare, som i (5), og visse komplekse tegn, der kan segmenteres, men som kan antages at være lagret som en usegmenterbar helhed, som i (6).

(3) Fy!

(4) Hejsa!

(5) Gimmefood!

(6) When in Rome, do as the Romans do.

På basis af den funktionelle teori (se afsnit 2 ovenfor) kan man begynde med at fastslå, at holofraser ikke er grammatiske tegn. Grammatiske tegn er kendetegnet ved, at de ikke kan stå alene, men kræver at blive kombineret med et 'værts'-tegn, i forhold til hvilket de har diskursivt sekundær status. Man kan observere, at det giver et afvigende resultat, hvis man prøver at give et grammatisk tegn status af en hel, selvstændig ytring:

(7) *-er! (dansk præsens-endelse)

(8) *It? (engelsk tryksvagt 3. persons pronomen)

(9) *Sgu! (diskurspartikel)

2 Der findes mange forskellige versioner af dependens i lingvistikken. Vi har valgt ikke at knytte vores ret enfoldige definition til et bestemt dependensteoretisk udgangspunkt. 
Omvendt lader holofraser sig ifølge den funktionelle definition ikke kombinere med andre tegn inden for samme ytring ${ }^{3}$. Fordi de udgør eneste element i en ytring, er holofraser nødvendigvis diskursivt primære - der er ikke andre tegn i ytringen, de kan konkurrere med om diskursprominens. Grammatiske elementer er i modsætning hertil diskursivt sekundære pr. konvention.

I næste omgang kan man imidlertid også fastslå, at holofraser heller ikke er leksikalske tegn. Leksikalske tegn er ganske vist defineret ved at være potentielt diskursivt primære - men de er netop ikke altid primære. I nedenstående ytringer kan man vælge, hvilke af de leksikalske elementer der skal have primær status i et konkret tilfælde. I $(10)(=(1))$ står valget mellem ordene undgå og kål, i (11) står det overordnet set mellem helsætningen og ledsætningen.

(10) Undgå kål!

(11) Jeg er sikker på, der snart kommer sne.

Nogle leksikalske tegn kan stå alene og derved vikariere som holofraser, jf. (12) og (13), men det gælder ikke alle. Mange kræver kombination med andre tegn, jf. (14).

(12) Brand!

(13) Skiderik!

(14) *Vidste!

Det er desuden karakteristisk, at ord der fungerer som holofraser, også naturligt associeres med en ganske bestemt illokutionær værdi, hhv. 'advarsel' og 'udskældning' i (12) og (13). Et ord, der alene skal udgøre en ytring, må i sagens natur også kunne fungere som en komplet talehandling, dvs. have en indbygget illokution.

Holofraser er altså hverken leksikalske tegn eller grammatiske tegn. De må udgøre en selvstændig tredje tegntype.

3 Nogle interjektioner udviser en variation, der kan tolkes som udtryk for en begrænset kombinatorik (hej med dig/jer, av for den/Søren/Pokker), men i reglen står de alene i en ytring, og under alle omstændigheder er det kun, når de står alene, de kan betragtes som holofraser. 


\section{Tre slags sproglige tegn}

I stedet for altid at tage udgangspunkt i en tvedeling, hvor tegn enten må være leksikalske eller grammatiske, har vi nu udbygget tegntypologien, så der fremstår følgende tre typer: holofraser, leksikalske tegn og grammatiske. De tre typer kan adskilles ved deres dependens- og diskursprominensforhold. Holofraser er eneste tegn i en ytring og altid diskursivt primære. Leksikalske tegn er undertiden eneste tegn i en ytring og gæsteoptræder så som holofraser. Denne mulighed følger principielt af, at leksikalske tegn potentielt kan udtrykke det primære indhold i en ytring. Men leksikalske tegn kan som sagt også være diskursivt sekundære. Grammatiske tegn er aldrig eneste tegn i en ytring og er altid diskursivt sekundære (uden for metasproglige kontekster). Disse forskelle er opsummeret i tabel 1.

\begin{tabular}{|l|l|l|}
\hline & Dependensforhold & Diskursprominensforhold \\
\hline Holofraser & Eneste tegn i en ytring & Diskursivt primære \\
\hline Leksikalske tegn & Undertiden eneste tegn i en ytring & Enten primære eller sekundære \\
\hline Grammatiske tegn & Aldrig eneste tegn i en ytring & Altid sekundære \\
\hline
\end{tabular}

Tabel 1: Dependens- og diskursprominensforhold for holofraser, leksikalske tegn og grammatiske tegn

Den fælles kontrast til holofraser tydeliggør et fællestræk ved leksikalske og grammatiske tegn. De forudsætter begge kompleksitet i ytringen og repræsenterer dermed en arbejdsdeling. De tre slags tegn kan således karakteriseres med hjælp af to dikotomier. Holofraser er simplekse størrelser uden intern struktur, mens grammatiske og leksikalske størrelser er dele af komplekse tegn. Leksikalske størrelser kan i forhold til de ytringer, de indgår i, være det primære indhold, men det kan grammatiske tegn ikke, fordi de pr. konvention er sekundære. De to dikotomier er illustreret i figur 1.

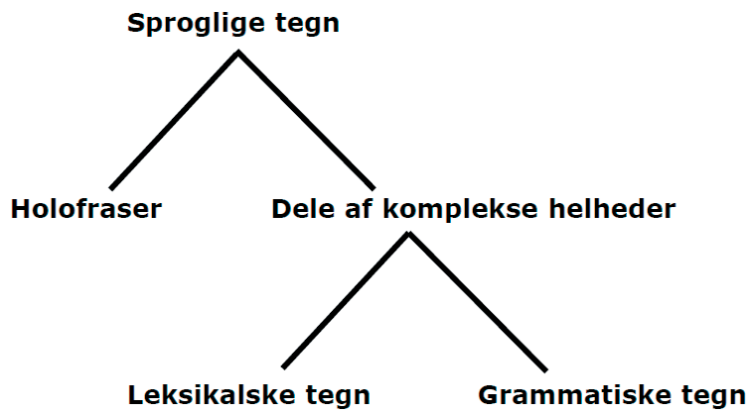

Figur 1: To dikotomier 
Begge dikotomier har neurolingvistiske korrelater. Dikotomien mellem leksikalske og grammatiske tegn modsvares (i hvert fald i nogen grad) af en kontrast mellem områder i (hos de fleste) venstre hjernehemisfære, der understøtter de to slags tegn, og en tilsvarende kontrast mellem på den ene side ikke-flydende afasi, der afficerer produktionen af grammatiske tegn mere end produktionen af leksikalske, og på den anden side flydende afasi, der afficerer produktionen af leksikalske tegn mere end produktionen af grammatiske (fx Boye \& Bastiaanse 2018).

Den anden dikotomi - mellem holofrastiske og kompleksitetsforudsættende tegn - modsvares muligvis (i nogen grad) af en kontrast mellem områder i hjernebarken i (hos de fleste) hhv. højre og venstre hemisfære, der understøtter de to slags tegn. Således forbinder bl.a. Damasio (1992) holofraser ("automatic idioms") med højre hemisfære:

In short, the right hemisphere cortices are not concerned with the core phonetic, lexical, and grammatical processes whose impairment hallmarks aphasia. But they contribute critical aspects of normal language processing: automatic idioms, prosody, and discourse (Damasio 1992: 537).

I overensstemmelse hermed må det antages, at produktionen af sætninger og syntagmer og dermed leksikalske og grammatiske tegn forudsætter andre kognitive evner end produktionen af holofraser, Holofraser hentes og gemmes som helheder, så de forudsætter blot en evne til at hente og gemme tegn. Leksikalske og grammatiske tegn forudsætter også denne evne, men derudover en evne til at kombinere og segmentere tegn.

Det er værd at understrege både forskellen og ligheden mellem leksikalske tegn og holofraser. Ligheden består i, at ingen af de to tegntyper er hjælpekonstruktioner - de bærer på et indhold, som kan udgøre hovedpointen i en ytring. Forskellen består i, at holofraser, fordi de selv skal bære en hel ytringsbetydning, udgør et lukket og begrænset inventar af ting, man kan sige. Det kan illustreres med dyrekommunikation: Man kan opstille et komplet repertoire af, hvad dyr af en bestemt art kan sige til hinanden, fordi dyr (med ubetydelige undtagelser) ikke kan kombinere simple tegn til komplekse. Omvendt dækker menneskesprogs holofraser kun et meget begrænset udsnit af menneskelige kommunikationsbehov.

Overgangen fra et system bestående af simple tegn til et system med mulighed for kombination af simple tegn til komplekse tegn betinger således ikke kun fremkomsten af grammatiske tegn. Også leksikalske tegn 
er afhængige af et system med kombinerbarhed. Den åbne inddragelse af betydning hentet fra alverdens mangfoldighed, som er karakteristisk for leksikalsk betydning, udgør ikke uden videre meningsfulde meddelelser i sig selv. Mennesker går ikke rundt og siger passatvind, peristaltisk eller uddrage til hinanden. Selve arbejdsdelingen mellem leksikon og grammatik er en del af overgangen fra et simpelt til et komplekst, struktureret tegnsystem. Denne komplekse arbejdsdeling har andre aspekter end opgavefordelingen mellem grammatiske og leksikalske størrelser - men denne opgavefordeling udgør en central del af denne epokale overgang. Det vender vi tilbage til $\mathrm{i}$ afsnit 6 nedenfor.

\section{Formularer}

Fremstillingen ovenfor kompliceres af såkaldte formularer eller frasemer, dvs. faste tegnkombinationer såsom engelsk kick the bucket, der tilsyneladende er komplekse, men i realiteten simple tegn, der kan antages at være lagret som helheder. Formularer har spillet en vigtig rolle også i den teoretiske litteratur, fordi de peger på en undtagelse til det, der en overgang (specielt i generativ lingvistik) blev betragtet som adelsmærket for menneskesprog, nemlig evnen til at bygge komplekse ytringer op fra mindstebestanddele - at kombinere sig frem til uendelig mange udtryksmuligheder ud fra et endeligt inventar af tegn. Man har talt om brugen af allerede foreliggende kombinationer som et ligeværdigt alternativ til brugen af kombinationsevnen og påpeget at det udgjorde et mindre processeringskrævende alternativ til muligheden for hver gang at starte med mindstedelene. En gennemgang af denne problemstilling kan findes i Wray (2002).

Komplikationen består i, at holofraser har ligheder med formularer. For det første gemmes og hentes begge som helheder. For det andet er der som påpeget af Wray en parallel mellem dem derved, at de sparer taleren for processeringsomkostninger i forbindelse med kombinationsarbejdet. Holofraser sættes derfor ofte lig med formularer. For eksempel noterer Sidtis et al. (2018) sig, at personer med afasi ofte falder tilbage på "unitary utterances" (= holofraser):

Prominent aphasiologists in the 20th century invariably mentioned the dramatic contrast between these preserved, well-articulated unitary utterances and disordered, newly created speech (Sidtis et al. 2018: 190). 
De giver følgende eksempler på "unitary utterances":

(15) He could talk a mile a minute

(16) On the face of the earth

(17) Vanishes in a puff of smoke

Men her overser de det forhold, at holofraser ikke kun har én særlig egenskab, nemlig den, at de gemmes og hentes som helheder. De har tillige den egenskab, at de udgør hele ytringer. Hvor (15) er en oplagt kandidat til en hel ytring, er (16) og (17) usandsynlige som hele ytringer. Fx kalder (17), vanishes in a puff of smoke, helt oplagt på kombination med et subjekt.

Det betyder, at ikke alle formularer er holofraser. Ud over holofrastiske formularer som (15), må man således (i hvert fald) regne med leksikalske formularer. Det er formularer som (16) og (17), der kræver kombination med andre tegn, og som i sådanne kombinationer - ligesom alle andre leksikalske tegn - har potentialet til at være diskursivt primære, men ikke nødvendigvis er det. Måske kan man også forestille sig grammatiske formularer, dvs. formularer, der pr. konvention er diskursivt sekundære. Et muligt eksempel er det tyske parentetiske udtryk glaub' ich (som i: Wer immer strebend sich bemüht, den können wir erlösen, glaub' ich). Det opfylder kravene til at være en formular ved tilsyneladende at være en flertegnsforbindelse, men i realiteten at være en fasttømret enhed, og det er rimeligvis grammatikaliseret (se fx Boye \& Harder 2007 om parentetiske udtryk og grammatikalisering).

Vi får dermed en differentieret tegntypologi, der ser ud som i figur 2.

\begin{tabular}{|c|c|}
\hline \multicolumn{2}{|c|}{$\begin{array}{c}\text { HOLOFRASER } \\
\text { hurra, hej }\end{array}$} \\
\hline \multicolumn{2}{|c|}{$\begin{array}{l}\text { Holofrastiske formularer } \\
\text { She could talk a mile a minute }\end{array}$} \\
\hline $\begin{array}{l}\text { Leksikalske formularer } \\
\text { Vanishes in a puff of smoke }\end{array}$ & $\begin{array}{c}\text { Grammatiske formularer } \\
\text { Tysk glaub' ich }\end{array}$ \\
\hline $\begin{array}{l}\text { LEKSIKALSKE TEGN } \\
\text { bil, vide, gul }\end{array}$ & $\begin{array}{c}\text { GRAMMATISKE TEGN } \\
\text { Engelsk the, gonna, -ed }\end{array}$ \\
\hline
\end{tabular}

Figur 2: Differentieret tegntypologi 
Sondringen mellem holofrastiske, leksikalske og grammatiske formularer indebærer en hypotese, som kan nuancere diskussionen om faste udtryk i relation til afasi:

\section{Hypotese:}

Holofrastiske formularer bevares i afasi, mens grammatiske formularer afficeres i agrammatisk afasi, og leksikalske i flydende afasi.

\section{De tre slags tegn og grammatikkens fylogenese}

I det følgende vil vi placere de tre tegntyper, vi ovenfor har argumenteret for at skelne imellem, i et hypotetisk fylogenetisk scenarie.

\subsection{Det holofrastiske stadie}

Det antages ofte, at den første slags sproglige tegn var holofraser (fx Hurford 2011). Det er der flere grunde til at tro. Én er, at andre primater har tegnsystemer, som består af holofraser, jf. fx grønne makakers advarselskald (Cheney \& Seyfarth 1992). En anden grund er, at de første intentionelle sproglige tegn, der produceres af børn, typisk er holofraser (jf. også Tomasello 2003). Endelig adskiller holofraser sig som nævnt fra både leksikalske og grammatiske tegn derved, at de nødvendigvis må være diskursivt primære (der er kun ét sprogligt tegn, og der er derfor ingen konkurrence om diskursprominens). Også ud fra den betragtning udgør holofraser et naturligt startpunkt for kommunikation: Man starter med at have et simpelt budskab, og dette udgør indholdet i et tegn, der samtidig er hele ytringen.

\subsection{Dannelsen af komplekse tegn}

Spørgsmålet er så, hvilken udviklingsvej der fører fra holofraser til komplekse ytringer. Der kan principielt tænkes to veje, en syntetisk og en analytisk. Det syntetiske spor fører fra brug af enkeltstående tegn til sammenkobling af dem til komplekse tegn. Et rent illustrativt tankeeksperiment kunne være, at man som udgangspunkt havde demonstrativer som kunne bruges til at 'pege' med, således at man kunne henlede opmærksomheden på et fænomen ved at sige (se) der. ${ }^{4}-$ og man ved siden af havde substantiv-agtige

4 Det kan måske virke overraskende, at demonstrativer her opfattes som hhv. holofraser og leksikalske størrelser (snarere end som grammatiske), men jf. diskussionen i Boye \& Harder (2012). Kernen i betragtningen er, at demonstrativer som 'pege'-ord kan udgøre et ytringsindhold alene og samtidig kan indgå som diskursivt primært element i en grammatisk forbindelse med andre ord, som i: look at that! 
holofraser à la makakernes advarselskald for leopard og ørn. En dag kunne man så forestille sig, at man koblede et demonstrativ sammen med en advarselskategori og sagde that eagle! eller ørn der! sådan at man foretog to sammenhørende handlinger: en kategorisering af faren og en udpegning af dens placering.

Det analytiske spor ville foreligge, hvis man som sprogbruger startede med en fast vending, som man brugte som en uanalyserbar helhed - med samme eksempel som før: that-eagle! eller ørn-der! Senere ville man så gå over til at bruge hver del for sig. Dette er nok lettest at forestille sig som en del af ontogenesen, hvor det svarer til et aspekt af udviklingsmønstre fundet af Tomasello (2003): Børn starter med at bruge verber i faste kombinationer (á la $\left.h a^{\prime}-m o s\right)$ og går forst gradvis over til at kombinere mere frit (ha' mos, ha' malk etc.); 'the verb island hypothesis'. Men i fylogenesen er der ikke plausibelt grundlag for at antage en analytisk udviklingsstrategi (Hurford 2011; Heine \& Kuteva 2007: 25).

Hvis man afstår fra at spekulere i helt konkrete hypoteser om forløbet, kan man opstille en generel hypotese om den basale overgang fra simple til komplekse ytringer som en logisk udviklingssti, det er svært at komme uden om: Før man kan have tegnkombinationer, må man have simple tegn. Før man kan have strukturerede kombinationer, må man have muligheden for overhovedet at kombinere. Ikke-strukturerede kombinationer kan være svære at holde klart adskilt fra blot at bruge to ord efter hinanden, men er et nødvendigt mellemtrin (jf. Greenfield 1991: 533, 540 om pairing). Den afgørende overgang til ikke-struktureret kompleksitet kan have bestået i, at man begyndte at markere to-ordshelheder vha. pauser - eller mere præcist: at producere to ord inden for samme pausemarkerede ytring (se Hurford 2011: 608, 618).

\subsection{Dannelsen af strukturerede komplekse tegn og dermed af leksikalske tegn og grammatiske konstruktioner}

Ligesom der med overgangen fra encellede til flercellede organismer opstår et behov for en arbejdsdeling (jf. uddifferentieringen i fx muskelceller og nerveceller), opstår der med overgangen fra simple til komplekse ytringer et behov for en arbejdsdeling mellem forskellige typer tegn. Med behovet for arbejdsdeling følger behovet for struktur. Man kan forestille sig, at overgangen fra ikke-strukturerede til strukturerede tegn-kombinationer er sket ved en konventionalisering af pragmatisk motiverede og derfor højfrekvente kombinationsmønstre. Fx kan man forestille sig, at der på trinnet med komplekse, men ustrukturerede ytringer har været en tendens til at nævne 
det topikale tegn først, som med tiden er konventionaliseret til først en topic-comment-struktur og så måske en protosubjekt-protoverbal-struktur.

Under alle omstændigheder er overgangen til strukturerede kombinationer forbundet med dannelsen af den første grammatik: skematiske konstruktioner med to (undertiden måske tre) pladser. Sådanne konstruktioner er efter vores begreber klart grammatiske tegn. De er 'dependente', idet de ikke kan fungere, uden at de to pladser er udfyldt, og de har en diskursivt sekundær funktion: at indikere, hvad forholdet er mellem de to tegn, der udfylder pladserne. Samtidig er det først med dannelsen af strukturerede kombinationer, vi făr de første tegn, der er leksikalske i den forstand, vi kender det fra moderne sprog: Struktureringen af den komplekse ytring muliggør en uddestillering af forskellige ordklasser, således at fx protosubjektspladsen er blevet associeret med protosubstantiver, og protoverbalpladsen med protoverber.

Uanset hvordan denne overgang præcis har fundet sted, indebærer den en dobbeltbevægelse, som ikke kan begribes fuldt ud ved, at man nøjes med at sige, at man går over til at kombinere tegn i stedet for bare at bruge dem ét ad gangen. Det, der mangler, er den anden halvdel af udviklingen. Denne består i, at tegnene skifter karakter, når de kombineres - i stedet for at være autonome enheder bliver de underdele af en større helhed. Før man har kombinationer, har man således ikke et egentligt leksikon, men et 'holofrastikon'. Der kan således ikke tænkes ordklasser på det trin, hvor hvert enkeltord udgør en hel ytring, og der kan ikke tænkes ordklasser i den forstand, vi kender dem i dag, på et stadie, hvor der ikke også er struktur. Dobbeltbevægelsen kan også beskrives på den måde, at der både sker en kombination og samtidig en spaltning: Ytringen opdeles i mindre dele, samtidig med at ordene kombineres til en større helhed.

Igen finder man en analogi i cellernes udvikling. De celler, der indgår i en kompleks organisme, kan ikke længere klare sig selv - de bliver afhængige af hinanden for at kunne fungere. På samme måde kan de nye, specialiserede tegntyper kun fungere ved at samarbejde med hinanden inden for rammerne af en kompleks ytring.

\subsection{Dannelsen af segmentale grammatiske tegn}

Med fremkomsten af komplekse tegn bestående af grammatisk strukturerede leksikalske tegn har vi principielt set et menneskesprog; jf. at sprog i Mekong-Mamberamo-området er karakteristiske ved en "Low Grammatical Morpheme Density" (Gil 2015). På et stadie, hvor strukturerede komplekse tegn er tilstrækkeligt veletablerede, kan de imidlertid danne basis for en 
yderligere udvikling, der består i dannelsen af segmentale grammatiske tegn. Denne udvikling kan eksemplificeres med dannelsen af den bestemte artikel. Hvor demonstrativer som that bevarer evnen til at optræde alene, dvs. uden at være determinativer for et efterfølgende substantiv, kan de også optræde i kombinationer, hvor de grammatikaliseres. Dvs. de udvikler sig til et (segmentalt) tegn, the, der kun kan stå som determinativ, og som er dependent og diskursivt sekundært i forhold til et andet tegn.

\subsection{Funktionsbaseret struktureret kompleksitet}

Differentieringen i grammatiske og leksikalske tegn er, som det allerede er fremgået, ikke den eneste differentierede arbejdsdeling, der udvikler sig; også de forskellige ordklasser (substantiver, verber, adjektiver) er resultatet af en arbejdsdeling. Differentieringen mellem mere eller mindre højt prioriterede informationsdele tager også andre former end udviklingen af grammatiske over for leksikalske tegn - pragerskolens analyseapparat baseret på 'kommunikativ dynamik' (jf fx Firbas 1999) giver fx en gradueret beskrivelse af prioriteringsmekanismer i den syntaktiske organisering. Det særlige domæne for grammatiske tegn opstår, når bestemte tegn som en del af deres konventionelle bagage får den rolle at spille andenviolin i forhold til bestemte typer af leksikalske og dermed potentielt primære tegn.

Grammatikkens opståen er således et centralt, men ikke det eneste eksempel på 'struktureret kompleksitet' som et kendetegn for menneskesprog. En række opgaver for beskriveren har at gøre med dette overordnede kendetegn, snarere end kun at vedrøre det rent grammatiske. Hierarkisk organisering får således også konsekvenser for hvor i hierarkiet forskellige dele af det leksikalske indhold i en sætning skal placeres. Men denne kompleksitet kan ikke adresseres, uden at man ser det leksikalske i sammenhæng med det grammatiske. Det gælder fx spørgsmålet om, hvilke elementer der har skopus over hvilke, som har at gøre med den basale grammatiske organisering i sætningen.

Denne organisering er funktionelt baseret. Det gælder allerede det grundlæggende skridt fra ustrukturerede til strukturerede meddelelser, som når der opstår et protosubjekt og et protoverbal. Princippet er mere generelt end det rent sproglige og kan illustreres med udviklingen af et ikkesprogligt redskab som fx en kniv. Ur-kniven var formodentlig en skarp sten, og den havde karakter af et ustruktureret hele, der understøttede skære- og holde-funktionen under ét. Udviklingen af mere raffinerede redskaber havde som et afgørende skridt, at man opdelte kniven i to dele, nemlig bladet og skæftet. Herved blev genstanden differentieret ud i to dele med 
hver sin funktion. Skæftet dækkede behovet for at holde på kniven, mens bladet dækkede behovet for at kniven kunne bruges til at skære. Samtidig illustrerer eksemplet en uddifferentiering i et del-objekt, der tjener den primære funktion, og et del-objekt som har hjælpe-status. Det primære er bladet og dets funktion, nemlig at skære - en kniv, der kun er egnet til at holde fast i, ville ikke tjene noget funktionelt formål. Men skæftet har en hjælpe-funktion som sætter redskabet i stand til at tjene sit primære formål mere effektivt.

Også i forhold til dette eksempel er det vigtigt at understrege, at dette ikke betyder, at funktionsbaseret struktur, herunder tegnkategorier og strukturer, kan reduceres til kommunikativ funktion i en konkret situation. Skæftet eksisterer med den funktion at være håndtag også i situationer, hvor kniven ikke er i brug. Dette hænger sammen med, at grammatik opstår ved dannelsen af en konvention, ikke ved en situationsbestemt arbejdsdeling. Denne konventionelle karakter betyder, at kategorier og struktur kan leve videre, efter den funktion, der motiverede dem, er tabt. Igen kan man parallellisere med andre redskaber: Sikhernes kirpan fortsætter med at have et blad og et skæfte, uanset at den stort set aldrig anvendes til at skære.

\subsection{Den fylogenetiske hypotese}

Det kan være hensigtsmæssigt med et resumé af logikken i denne fylogenetiske råskitse. Med basis i foregående diskussion kan man opstille en fylogenetisk hypotese med fire idealtypiske trin, der er illustreret i figur 3 nedenfor.

1. Holofraser

\section{Dog!}

2. Tegnkombinationer

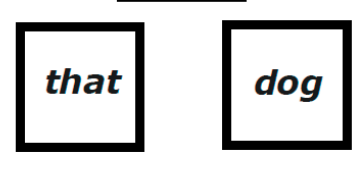

3. Strukturerede kombinationer af leksikalske tegn

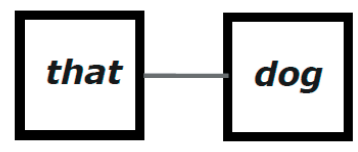

4. Deleksikalisering: fremkomst af grammatiske ord og morfemer

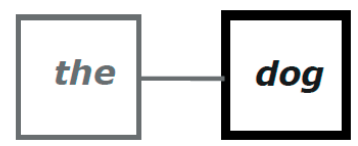


Hypotesen er baseret på elementære forudsætningsrelationer: For at have kombinationer af tegn (trin 2) må man først have tegn $(\text { trin } 1)^{5}$. For at have strukturerede kombinationer af tegn (trin 3), må man kunne kombinere dem (trin 2). Med trin 3 er man på et trin, som er principielt tilstrækkeligt til at have menneskesprog. Her består de grammatiske størrelser kun i kombinationsmønstre - der er ikke særlige grammatiske ord eller morfemer (som man under ét kan betegne 'segmentale' tegn). Trin 4 tilføjer imidlertid en udvikling, som har stået centralt i grammatikaliseringslitteraturen, nemlig hvad vi vil kalde deleksikalisering. Det eksempel, vi har anvendt (fra that dog til the $(0 g)$ ), eksemplificerer et af de klassiske eksempler, nemlig udviklingen af den bestemte artikel. I sammenhængen skal det stå som repræsentant for hele klassen af 'segmentale' grammatiske ord og morfemer, dvs. inklusive futurums-endelser i fransk osv. Ifølge denne udviklingshypotese kommer de skematiske konstruktioner altså først, mens de segmentale grammatiske tegn kun kan udvikle sig ved at tilpasse sig en strukturel plads i den større ramme.

Lad os samtidig opsummere, hvad forholdet er mellem denne fylogenetiske hypotese og ontogenesen, altså den enkelte sprogbrugers tilegnelse af sproglig kompleksitet. Kan man antage, at den gentager fylogenesen, ligesom det $\mathrm{i}$ et vist omfang er tilfældet $\mathrm{i}$ biologien? Her er det vigtigt at betone, at sproglige strukturer grundlæggende er sociokulturelle, og at sociokulturel overlevering er kumulativ (jf. Tomasello, Kruger and Ratner 1993). Det betyder, at den er kendetegnet ved den såkaldte ratchet effect ('skraldeeffekt'). Dette træk indebærer, at den sproglige ontogenese har andres færdigstrukturerede ytringer at bygge på. Derfor skal ikke alt opbygges fra grunden. Børn kan imitere komplicerede ytringer som helhed og dermed benytte dem som holofraser - og langsomt differentiere (abstrahere) dem ud i bestanddele. ${ }^{6}$

5 Det allerførste, der må forudsættes - forud for dannelsen af tegn af den slags, der findes i moderne sprog - er kommunikation, altså udveksling af meddelelser. Udgangspunktet for den differentieringsprocess, som vi opstiller, er 'ytringsindhold'. Den første overgang består således i, at man går over til at kommunikere hele ytringsindhold ved hjælp af tegn, der i sig selv ikke kommunikerer et helt ytringsindhold, men kun et fragment af ytringsindholdet.

6 Tomasellos (2003) egen analyse af tilegnelsesprocessen er baseret på konstruktionsgrammatik, der nedtoner forskellen på leksikalske og grammatiske elementer, og den er derfor ikke orienteret imod at besvare spørgsmålet om, i hvilket omfang tilegnelsen af grammatiske tegn efterfølger tilegnelsen af leksikalske. 


\section{Opsummering}

I bl.a. Boye \& Harder (2012) har vi argumenteret for en funktionel sondring mellem grammatiske og leksikalske tegn, hvis omdrejningspunkt er en forståelse af grammatiske tegn som tegn, der er konventionaliseret med en af de to mulige diskursprominensværdier for leksikalske tegn: Grammatiske tegn er pr. konvention diskursivt sekundære og dermed dependente i forhold til leksikalske 'værts'-udtryk.

Et af to hovedformål med denne artikel var at placere holofraser i forhold til den funktionelle sondring. Vi har argumenteret for, at holofraser udgør en selvstændig tredje tegntype, og at man altså må operere med tre typer af sproglige tegn: grammatiske, leksikalske og holofrastiske. Vi har ligeledes argumenteret for, at der er et vigtigt fællestræk ved grammatiske og leksikalske tegn, som synliggøres af den fælles kontrast til holofraser: I modsætning til holofraser forudsætter begge tegntyper struktureret kompleksitet, og de repræsenterer en arbejdsdeling mellem dele af komplekse helheder. Som et led i argumentationen har vi behandlet en type tegn, som umiddelbart fremstår med en uklar placering i tegntypologien, nemlig de såkaldte formularer. De har det træk fælles med holofraser, at de fungerer som ét tegn, selvom de tilsyneladende er komplekse, og de behandles derfor i litteraturen undertiden på samme måde som holofraser. Mange formularer udgør imidlertid ikke en hel ytring, men er egentlig leksikalske eller grammatiske størrelser, idet de kan indgå som bidrag til en større, kompleks helhed, der fungerer som en ytring.

Det andet hovedformål med artiklen var at indplacere de tre tegntyper i et fylogenetisk scenarie. Scenariet antager, at de forste tegn var holofraser, og at de første ytringer altså bestod af simple, holofrastiske tegn. På efterfølgende udviklingstrin opstod der først ustrukturerede komplekse ytringer og siden grammatisk strukturerede komplekse ytringer. Her gik simple størrelser sammen om at danne større helheder, idet de samtidig blev nedgraderet fra at være frie enheder til at være underdele af en kompleks helhed. Med de grammatisk strukturerede ytringer fremkom for det første grammatiske skematiske konstruktioner, som bærer struktureringen, og hvis funktion det er at indikere, hvad forholdet er mellem de segmentale tegn, der udfylder konstruktionernes pladser. For det andet fremkom - ved en differentiering betinget af konstruktionernes 'pladser' (fx protosubjekt og protoverbal) - leksikalske tegnklasser (fx protosubstantiver og protoverber). Dermed opstod fuldt funktionsdygtige menneskesprog. I en efterfølgende udvikling har den prioritiering mht. diskursprominens, som kompleksiteten nødvendiggør, imidlertid via konventionalisering af diskursivt sekundær 
status ført til dannelsen af segmentale grammatiske tegn. Det fylogenetiske scenarie indebærer altså, at grammatiske tegn falder i to undertyper: skematiske konstruktioner og segmentale tegn.

Vores hovedpointe om en funktionelt baseret arbejdsdeling mellem leksikalske og grammatiske tegn afviger sammen med vores teoretiske udgangspunkt fra den grundantagelse, der associeres med konstruktionsgrammatikken, ifølge hvilken sprog bedst forstås som et kontinuum, der omfatter såvel grammatiske som leksikalske træk ved de enkelte tegn, der under ét opfattes som konstruktioner. Den afviger imidlertid også fra den generative opfattelse, der er udtrykt bl.a. af Pinker (1999), hvorefter grammatik og leksikon er to helt forskellige typer af sproglige fænomener.

\section{Om forfatterne}

Kasper Boye, ph.d., lektor i lingvistik, Institut for Nordiske Studier og Sprogvidenskab, Københavns Universitet.

Peter Harder, dr.phil., professor emeritus, Institut for Engelsk, Germansk og Romansk, Københavns Universitet.

\section{Litteratur}

Boye, K. \& P. Harder (2007): Complement-taking predicates. Usage and linguistic structure. Studies in Language 31.3, 569-606.

Boye, K. \& P. Harder (2012): A usage-based theory of grammatical status and grammaticalization. Language 88.1, 1-44.

Boye, K., \& R. Bastiaanse (2018). "Grammatical versus lexical words in theory and aphasia: Integrating linguistics and neurolinguistics". Glossa: a journal of general linguistics, 3.1, 29. DOI: http://doi.org/10.5334/ gjgl.436

Boye, K., M. Messerschmidt, J.S. Hansen \& V. Schaffalitzky de Muckadell (2019): Grammatikalisering af danske præpositioner. $\mathcal{N y}$ forskning i grammatik 26, 4-21.

Cheney, D.L. \& R.M. Seyfarth (1992): Précis of how monkeys see the world. Behavioral and Brain Sciences 15, 135-182.

Damasio, A.R. (1992): Aphasia. The New England Journal of Medicine 326.8, 531-539.

Firbas, J. (1999): Communicative dynamism. I: Handbook of Pragmatics (1999 Installment).J. Verschueren, J.-O. Östman, J. Blommaert \& C. Bulcaen (red.). Amsterdam: John Benjamins, 1-14. 
Gil, D. (2015): The Mekong-Mamberamo Linguistic Area. I: Languages of Mainland Southeast Asia. The state of the art. N.J. Enfield \& B. Comrie (red.). Berlin: DeGruyter Mouton, 266-355.

Gkalitsiou, Z., C.T. Byrd, L.M. Bedore \& C.L. Taliancich-Klinger (2017): Stuttering on function words in bilingual children who stutter: A preliminary study. Clinical Linguistics \&O Phonetics 31.10, 791-805.

Greenfield, P.M. (1991): Language, tools and brain: The ontogeny and phylogeny of hierarchically organized sequential behaviour. Behavioral and Brain Sciences 14, 531-595.

Harbsmeier, C. (1979): Wilhelm von Humboldts Brief an Abel-Rémusat und die philosophische Grammatik des Altchinesischen. Stuttgart: Friedrich Frommann Verlag.

He, Q. (1998): Chinese grammatical studies by Christian missionaries: Centering on those by the 19th century English protestants. Hitotsubashi Research 23.3, 27-36.

Heine, B. \& T. Kuteva (2007): The Genesis of Grammar. Oxford: University Press.

Hurford, J.R. (2011): The origins of grammar: Language in the light of evolution, vol. II. Oxford: Oxford University Press.

Ishkhanyan, B., H. Sahraoui, P. Harder, J. Mogensen \& K. Boye (2017): Grammatical and lexical pronoun dissociation in French speakers with agrammatic aphasia: A usage-based account and ERF-based hypothesis. Journal of Neurolinguistics 44, 1-16.

Kirchhoff, R. (2008): Die Syncategoremata des Wilhelm von Sherwood: Kommentierung und historische Einordnung. Leiden: Brill.

Klima, Gyula (2005): 'Syncategoremata'. I: Encyclopedia of language and linguistics, 2. udg. Keith Brown (red.). Oxford: Elsevier, 353-356.

Lyons, J. (1968): Introduction to theoretical linguistics. Cambridge: Cambridge University Press.

Messerschmidt, M., K. Boye, M.M. Overmark, S.T. Kristensen \& P. Harder (2018): Sondringen mellem grammatiske og leksikalske præpositioner. Ny Forskning i Grammatik 25, 89-106.

Pinker, S. (1999): Words and Rules. The ingredients of Language. New York: Basic Books.

Sidtis, J.J., D.V.L. Sidtis, V. Dhawan \& D. Eidelberg (2018): Switching Language Modes. Complementary Brain Patterns for Formulaic and Propositional Language. Brain Connectivity 8.3, 189-196.

Spruyt, J. (2011): Syncategoremata. I: Encyclopedia of medieval philosophy: Philosophy between 500 and 1500. H. Lagerlund (red.), Berlin: Springer, 1241-1245. 
Tomasello, M. (2003): Constructing a language. A usage-based theory of language acquisition. Cambridge, MA: Harvard University Press.

Tomasello, M., A.C. Kruger \& H.H. Ratner (1993): Cultural Learning. Behavioral and Brain Sciences 16, 195-552.

Wray, A. (2002). Formulaic Language and the Lexicon. Cambridge: Cambridge University Press. 